\title{
視覚障害ユーザにおける 白杖を用いた対象のテクスチャー認知における握り方の影響
}

The effect of a manner to grasp a white cane on object's texture perception.

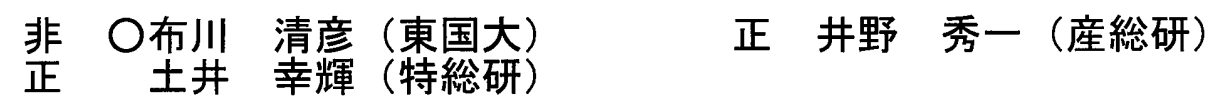

T Kiyohiko NUNOKAWA, Tokyo International University, 2509, Matoba, Kawagoe Shuichi INO, National Institute of Advanced Industrial Science and Technology Kouki DOI, National Institute of Special Needs Education

Key words : white cane, a manner to grasp, texture, people with visual impairment

\section{1.はじめに}

白杖は視覚障害者の単独歩行を支援する道具として, 最も 広く使われている物の一つである. 白杖ユーザは白杖を利用 しながら路面情報や障害物の有無を検知し, 移動のための手 がかりとなるランドマーク情報を収集・確認する. 白杖本来 の機能は, 基本的には石突きと物体との接触による反響音や 接触情報を利用して, 路面の状況や障害物の存在等を認識す ることであり，障害物そのものが何であるのかを詳細に認識 寸ることは必要ではない，しかし研究の実施にあたり，あら かじめ白杖ユーザに行った白杖利用に関するヒアリングで は, 訓練期間を経て, 日常生活において白杖を用いる際には, 白杖に触れた対象の特性を探ったり，対象の認知を行ったり といった，自分なりの利用方法を用いて環境認知を行ってい るという報告があった．従って，白杖を用いて対象のどの様 な属性を認知できるのかを明らかにすることで, 視覚障害者 の移動環境内のデザインにその情報を応用することが期待 できる. 環境認知のための白杖利用の方法について検討する ために, 先行研究では, 利き手の人差し指（示指）の先と利 き手で握った白杖のそれぞれでゴムを吒くか，または押すと いう方法でゴムの硬さ感覚についてマグニチュード推定を 行った。 その結果, 指先を用いるよりも，白杖を用いて対象 を確認した方が, 硬さの違いについては感度が良い事が明ら かになった（布川，2008;2009）。次にアイマスク，耳栓とイ ヤーマフを装着して視覚情報と聴覚情報を制限した晴眼大 学生を参加者として, 示指の先と白杖を用いた場合の粒子径 の大きさと肌理の粗さ (テクスチャー) 感覚の関係を明らか

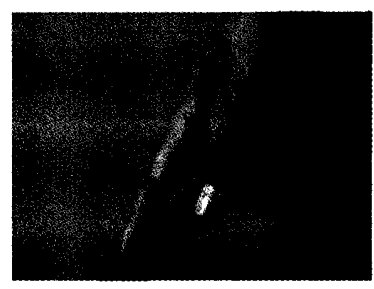

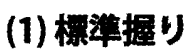

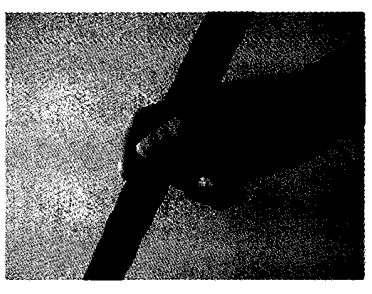

(2)ペン握り

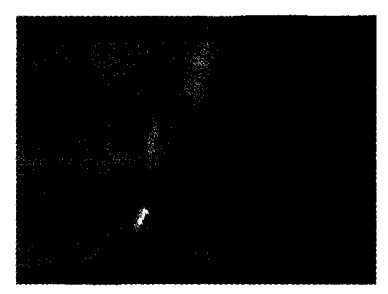

(3) 包丁握り

Fig.1 The three types of a manner to grasp a white cane.

にすることを試みた（布川他，2012）。白杖の握り方は，利 用されることの多い次の 3 種類を用いた (Fig.1).1) 白杖の グリップの平らな面に人差し指をのばした状態で合わせ, 親 指と他の三指で軽く握る方法（標準握り），2）鉛筆を持つよ うにしてグリップ部分を握る方法 (ペン握り)，3）親指を グリップの平らな部分に当て四指で握りこむ方法（包丁握 り). その結果を Table1にまとめた。 得られた全ての幕指数 が 1 よりも小さく, 粒子径が増加しても肌理の粗さの感じは それほど増加しない,つまり粒子径の変化に対する感度が低 い. 硬さに関する先行研究では, 睛眼大学生を参加者として 白杖を用いた場合には, 示指で直接触るよりも幕指数が大き く, 白杖によって硬度の変化に対する硬さ感覚が高まる傾向 が見られた。しかし，肌理を対象とした場合，白杖を用いた ことで, 示指で直接触るよりも粒子径の変化に対する肌理の 粗さ感覚が減少した。また，硬さにおいては標準握りと包丁 握りよりも, ペン握りの票指数が大きいことから，白杖を利 用して対象の硬さを認知する際に握り方が影響し，ペン握り が最も感度が良い事になる。しかし，肌理を対象とした実験 では, 標準握りと包丁握り票指数はペン握りよりも大きく, ペン握りが最も感度が悪いという結果であった。

Table 1 Exponents of power function for texture sensation in the three manners to grasp a white cane without sound by sighted university students.

\begin{tabular}{|c|c|c|c|c|}
\hline & 示指 & 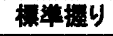 & ペン整り & 뇔丁提り \\
\hline 需指数 & 0.56 & 0.37 & 0.25 & 0.34 \\
\hline $\mathbf{R}^{2}$ & 0.93 & 0.79 & 0.79 & 0.95 \\
\hline
\end{tabular}

本研究では, 日常生活において白杖を利用しながら単独歩 行している全盲者 7 名を参加者として， 3 種類の握り方を 用いて肌理の粗さ感覚における白杖の握り方の効果につい て検討する。

\section{2. 実験}

実験は，聴覚情報情報を制限した条件（音なし）下で，人 差し指の腹部（実験 1) と 3 種類の握り方で握った白杖（実 験 2 から 4）という4 種類の確認方法で行った.

\section{1 刺激材料}

肌理の粗さを推定する対象として, 18 種類の耐水研磨紙 （三共理化学株式会社）を用いた。研磨紙の平均粒子径は, 6.7 (\#2000) から $279 \mu \mathrm{m}$ （\#60）であった（括弧内は粒度）。

2.2 白杖

白杖 (ジオム社) は, 主体がアルミニウム合金シャフトで, 長さは $1200 \mathrm{~mm}$ であった。そのうち、ゴムのグリップ部は $260 \mathrm{~mm}$ で，ナイロン製石突部が $75 \mathrm{~mm}$ であった（Fig.2）。 た，重さは約 $200 \mathrm{~g}$ であった。 

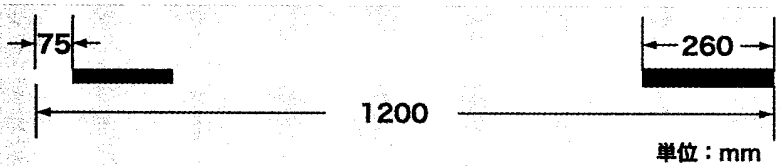

Fig.2 Size of a white cane.

\section{3 実験参加者}

日常的に白杖を利用しながら単独歩行している全盲者 7 名. 参加者は, 実験に入る前に木製の円盤（直径を変数とす る）を用いて，マグニチュード推定の手続きについて練習を 行った，実験に際しては，アイマスクと，耳栓をした上にイ ヤーマフを装着した。

Table 2 Properties of participants.

\begin{tabular}{cccc}
\hline ID & 年齡 (年:月) & 失明時期 & 白杖歴 (年:月) \\
\hline A & $40: 2$ & 0 & $37: 2$ \\
B & $29: 10$ & 11 歳頃 & $16: 0$ \\
C & $41: 2$ & 0 & $35: 2$ \\
D & $41: 8$ & 0 & $31: 8$ \\
E & $23: 0$ & 1歳半 & $17: 1$ \\
F & $22: 0$ & 7歳頃 & $15: 0$ \\
G & $23: 11$ & 0 & $17: 0$ \\
\hline
\end{tabular}

\section{4 手続き}

耐水研磨紙は, 縦 $1 \mathrm{~cm} \times$ 横 $25 \mathrm{~cm}$ に切り取られたスリット を持つ型紙を上に載せ, 人差し指の腹部がスリットを通して 接するように指の接触範囲を制限した。参加者椅子に座り， その前に机を配置し, 参加者正面の位置に耐水研磨紙を置い た (Fig.3).

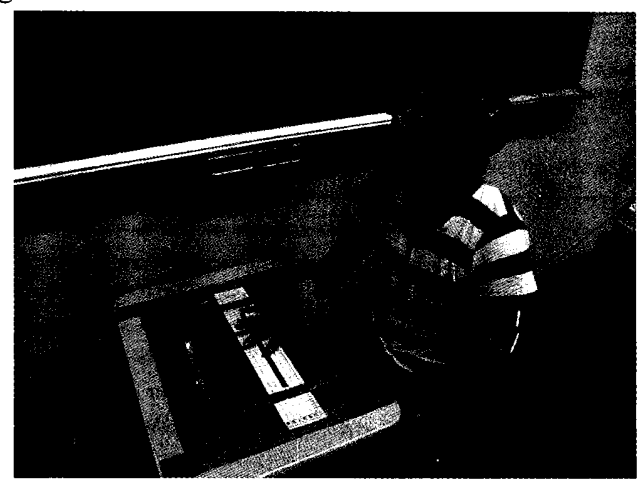

Fig.3 The Index finger experiment setting.

実験に入る前に, 楽な姿勢で推定ができるように位置関係 を調整した，参加者は，五指を広げ，人差し指だけをやや下 方に向けて空中に止めた. 実験者は参加者の人差し指の先を, 耐水研磨紙の上に乗せられた型紙のスリット脇に用意した スタート位置に誘導し, 実験者の合図に従って参加者自身が 非利き手側から利き手側にスリットに沿って指を移動させ て耐水研磨紙をなぞり, 肌理の粗さの推定值を報告した. 教 示では, 各粒子径（耐水研磨紙）に対して感じた肌理の粗さ を，それに相当する数を割り当てて報告するように指示した. 值の決まった標準刺激やモデュラスは用いなかった. 各粒子 径についてそれぞれ 1 回のマグニチュード推定を行った.

次に参加者は床に立ち, その正面の床の上に耐水研磨紙が 枠に固定された（Fig.4）. 耐水研磨紙は, 床の上に縦 $23 \mathrm{~cm} \times$ 横 $25 \mathrm{~cm}$ の枠で固定された. 参加者は指示された握り方で白 杖を握った. 実験者は, 白杖の先を耐水研磨紙の脇の位置に 誘導した，観察者は，実験者の合図で白杖の先が板に当たっ て止まるまで非利き手側から利き手側に耐水研磨紙上を水 平方向になぞるように動かした. そして, 肌理の粗さの推定
值を報告した。教示では，示指条件と同様に，各粒子径（耐 水研磨紙）に対して感じた肌理の粗さを, それに相当する数 を割り当てて報告するように指示した。值の決まった標準刺 激やモデュラスは用いなかった. 各粒子径（耐水研磨紙）に ついてそれぞれ 1 回のマグニチュード推定を行った. 耐水研 磨紙 18 種類の提示順序は, ランダムであった. 18 種類の耐 水研磨紙の推定を行ったら, 次の握り方で推定を繰り返した. 握り方の順序もランダムであった. 3 種類の握り方の全てで 推定を行って実験終了とした。

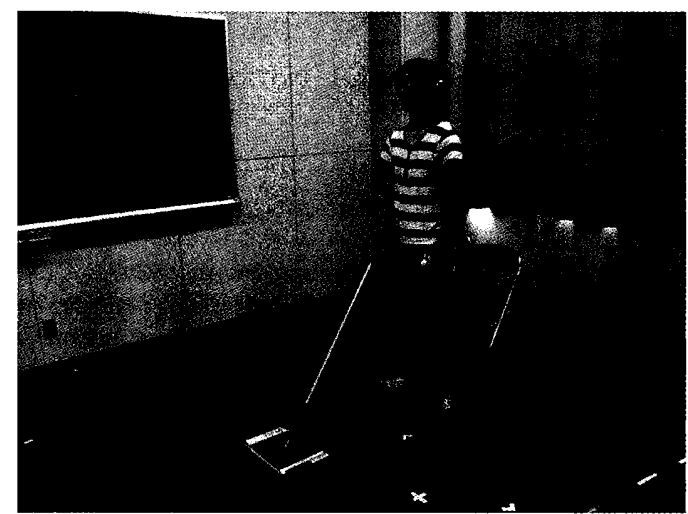

Fig.4 A white cane experiment setting.

\section{3. 結果と考察}

得られたマグニチュード推定值の幾何平均を算出し, 両対 数グラフの横軸に粒子径 $(\mu \mathrm{m})$, 縦軸に推定值をとってプ ロットし，幕関数で近似した（Fig. 5).

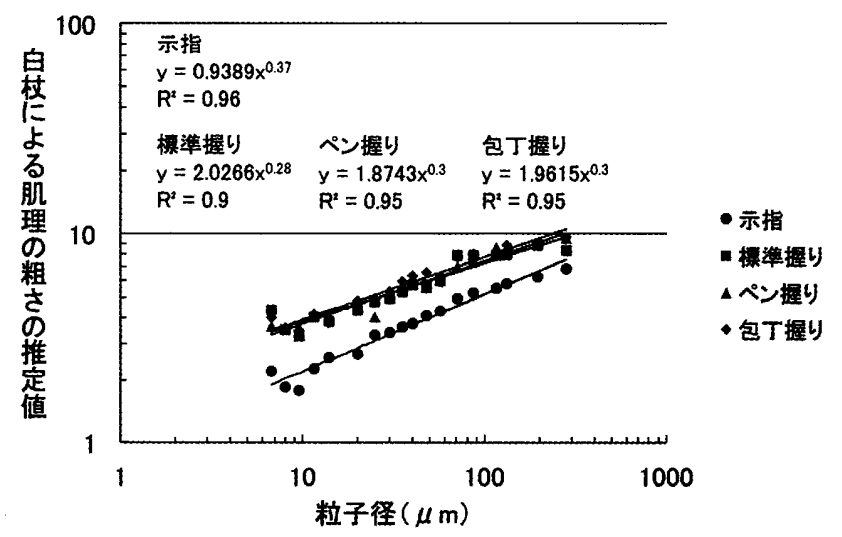

Fig.5 The function of the Particle size and texture sense without sound by white cane users.

その結果, 聴覚情報を制限した利き手の示指と白杖の全て の条件で幕指数が 1 よりも小さかったため, 粒子径がかなり 増加しても肌理の粗さの感じはそれほど増加しない,つまり, 粒子径の変化に対する感度が低いと言える. 白杖では全ての 握りが 0.3 程度で同じ程度に感度が悪かったことから, 握り 方は感度に影響しないと言える.晴眼大学生の結果 (Table 1) では，示指が 0.56 とやや幕指数が大きかったが，全盲者で は示指が 0.37 と小さかった。全盲者では全体として感度が 低い. 睛眼大学生を参加者とした硬さに関する先行研究では, 白杖条件では, 示指で直接触るよりも幕指数が大きく, 白杖 によって硬度の変化に対する硬さ感覚が高まる傾向が見ら れた. しかし, テクスチャーを対象とした本研究では, 白杖 を用いたことで, 示指で直接触るよりも粒子径の変化に対寸 る肌理の粗さ感覚が減少した. 硬さ知覚においては, 聴覚情 報の有効性を示唆するような結果が得られていることから， 聴覚情報を制限しない条件についても検討する必要がある。 